This manuscript is a preprint that has been submitted for publication in GEOLOGY. It has not undergone peer review. Subsequent versions of this manuscript may have different content. If accepted, the final version of the manuscript will be available via the "Peer-reviewed publication DOI" link on this webpage. Please feel free to contact any of the authors directly. We welcome your feedback. 


\title{
The role of surface processes in basin inversion and breakup
} unconformity

\author{
Luke S. Mondy ${ }^{1}$, Patrice F. Rey ${ }^{1}$, and Guillaume Duclaux ${ }^{2}$ \\ ${ }^{1}$ Earthbyte Group, School of Geosciences, The University of Sydney, Sydney NSW 2006, \\ Australia \\ ${ }^{2}$ Université Côte d'Azur, CNRS, OCA, IRD, Géoazur, 06560 Valbonne, France.
}

\begin{abstract}
At divergent plate boundaries, extensional tectonics lead to subsidence, continental rifting and the formation of continental margins. Yet, within this extensional context, transient compressional structures (stress inversion) and phases of uplift (depth inversion) are frequently recorded with no corresponding change in plate motion. Changes in gravitational potential energy during the rifting process have been invoked as a possible source of compressional stresses, but their magnitude, timing and relationship with depth inversions remain unclear. Using high-resolution 2D numerical experiments of the full rifting process, we track the dynamic interplay between the far-field tectonic forces, loading and unloading of the surface via surface processes, and gravitational body forces. Our results show that rift basins tend to localize compressive stresses, they record transient phases of compressional stresses up to 30 $\mathrm{MPa}$ and experience a profound depth inversion, $2 \mathrm{~km}$ in magnitude, when sediment supply ceases, providing a novel explanation for the breakup unconformity, a well-documented phase of regional uplift typically associated to continental breakup.
\end{abstract}




\section{INTRODUCTION}

Continental divergence leads to normal faults, subsidence, continental rifting and eventually to the formation of conjugate continental margins. In this tectonic setting, it is surprising to frequently observe short transient episodes of basin inversion in the form of $\mathrm{i}$ / surface uplift, ii/ contractional re-activation of normal faults, iii/ long-wavelength, shallow-angle unconformities, and iv/ broad low-amplitude folds (e.g., Withjack et al., 1998; Lundin and Doré, 2002, 2011; Holford et al., 2014). Often, these transient episodes of basin inversion do not correlate with change in plates motion (Withjack et al., 1998; Schlische et al., 2003; Lundin and Doré, 2011), and in the absence of nearby collisional processes, the rift-push force is often invoked as a possible driver of contractional inversion (Dewey, 1989; Bott, 1992; Boldreel and Andersen, 1993; Keleman and Holdbrook, 1995; Withjack et al., 1998; Rey, 2001; Huismans et. al., 2001; Davis and Kusznir, 2002; Pascal and Cloetingh, 2009; Mondy et al., 2018). Here, we use $2 \mathrm{D}$ thermo-mechanical numerical experiments of lithospheric scale extension to document the dynamic evolution of continental margins from rifting to drifting. We track through time the stress and strain rate fields, as well as the vertical motion of the pre-rift basement. Results show temporally and spatially variable patterns of extension and compression of similar length scale to that described in nature. In addition, our experiments document a prominent depth inversion of the basement before breakup, from subsidence to uplift, which matches in amplitude and timing the well-documented breakup unconformity often recorded along continental margins (Falvey, 1974; Franke, 2013; Soares et al., 2012). The magnitude of this inversion depends non-linearly on the basins depth and its timing correlates with the waning of sediment supply due to the increasing distance of the continent. These results illustrate the importance of surface processes in the dynamics of continental rifting, and may explain some of the complexities of continental breakup (e.g. Péron-Pinvidic et al., 2007). 


\section{NUMERICAL EXPERIMENTS PARAMETERS AND SETUP}

Using 2D coupled thermo-mechanical experiments, we quantify the evolving stress field during the formation of continental margins. We use Underworld 2.0, an opensource finite-element numerical framework (Moresi et al., 2003, 2007; Beucher et al., 2019) to solve the Stokes equations to obtain velocity and pressure fields from which strain rate and stress tensors can be derived. Figure 1 summarizes key aspects of our experimental setup. All materials are viscoplastic, with the viscosity dependent on temperature stress, strain, strain rate and melt-fraction. Plastic behaviour for all rock materials is modelled via a Drucker-Prager yield criterion linearly sensitive to accumulated strain to simulate strain-weakening, which is clipped when the strain reaches $20 \%$. We also impose a stress limiter of $150 \mathrm{MPa}$ and $300 \mathrm{MPa}$ for the crust and mantle respectively, to approximate additional rheological processes such as Peierls creep, and to limit the strength of the lithosphere within observational range (Demouchy, et al., 2013; Zhong and Watts, 2013). The initial geotherm derives from imposing a surface temperature of $20{ }^{\circ} \mathrm{C}$ and a constant temperature of $1353^{\circ} \mathrm{C}$ from $140 \mathrm{~km}$ to the base of the model. The upper crust and sediments have a radiogenic heat production twice as large as that of the lower crust. This results in an initial temperature at the Moho of $520^{\circ} \mathrm{C}$. The base of the thermal lithosphere (i.e., isotherm $1350{ }^{\circ} \mathrm{C}$ ) initially at a depth of $140 \mathrm{~km}$ is let to evolves in a self-consistent manner (Fig. 1). To capture the decrease in viscosity due to partial melting, we impose a 3-order of magnitude viscosity decrease as melt fraction increases from the solidus to the liquidus. Since our code does not allow melt to escape from its source, we impose a maximum melt-fraction of $30 \%$ in the crust and $2 \%$ in the mantle. In our model, partial melting also impacts on the geotherm as latent heat energy is consumed in the process. All rheological and thermal parameters are listed in Supplementary Table 1. 
Extensional deformation is driven by applying a total divergent velocity of $1,2,3$, or $4 \mathrm{~cm} / \mathrm{yr}$, equally partitioned between the left and right vertical walls. Isostasy is achieved by imposing an upward traction at the base of the model matching the initial downward vertical stress. We apply a simple infilling rule to approximate surface processes. When air particles fall below $1 \mathrm{~km}$ below sea level, fixed through time at elevation $0 \mathrm{~m}$, they become sediment particles, which then record time of 'deposition'. Conversely, when a particle of rock material exceeds a given height, it is "eroded" by switching it to air material. Sedimentation is limited in time by a distance condition on adjacent tracers initially positioned one kilometre apart at the Moho. Once the distance between two adjacent tracer reaches an imposed threshold (we have tested $30,60,80$ and $100 \mathrm{~km}$ ) sedimentation stops. This prevents sediments from accumulating in the ocean far away from the continental source of sediments and allows to investigate how cessation of sediment supply impacts rifting. For comparison we also ran a suite of experiments in which no sediment input was imposed. Finally, we map the Andersonian stress regime throughout the lithosphere by determining which principal stress axes is within $30^{\circ}$ of vertical (Zoback, 1992; Mondy et al., 2018).

\section{RESULTS}

Tectonic evolution - Figures 2 and 3 show the outcome of the experiment under moderate divergence velocity (2 cm/yr), without (Fig. 2A, 3A) and with (Fig. 2B, 3B) sedimentation. When sediments are supplied, they fill the space between the top of the basement up to $1 \mathrm{~km}$ below sea level, until the condition for the cessation of sedimentation is met. The entire set of experiments are detailed in Suppl. Data Figure SF1-3. Deformation starts with a broad zone of lithospheric thinning centred on the damaged region. Necking of the lithospheric mantle initiates and progresses rapidly allowing for the formation of a dome of asthenosphere in which decompression melting occurs (Fig.2 A1-2, B1-2). When present, sediments accumulate into a 
broad and deep basin, above the subsiding attenuated crust (Fig. 2 B1-3). Before breakup, this basin is stretched and boudinaged into a number of sub-basins bounded by normal faults (Fig. 2 B3-4). In the absence of sediment supply, the transition rift-to-drift occurs at $\sim 30 \%$ extension, compared to $\sim 50 \%$ when sediments are present. At this stage, steady-state oceanic spreading accommodates continental divergence, and deformation in the continental margins ceases. We observe that the deposition of sediments mitigates the mechanical thinning of the crust and favours the accumulation of extension before breakup. The presence of sediments also slightly slows down the necking of the lithospheric mantle and the onset of decompression melting, as shown by the larger region of decompression melting in the asthenosphere in the experiment without sediment (Fig. 2 A1-3).

Stress field evolution- Despite steady extensional velocity, all our experiments reveal a dynamic stress field with regions shifting from extension to compression as divergence proceeds (Fig. 3). In all experiments, the lithospheric mantle records stress regime inversion from extension to compression when a significant dome of asthenosphere has formed. In experiments with no sedimentation, the crust shows shallow regions of transient and moderate syn-rift compression (up to $10 \mathrm{MPa}$ ), developing most clearly in experiments driven by faster extensional velocities. In experiments with sedimentation, we observe that stress inversion tends to localize around sub-basins (red arrows in Figure 3B2, 3B4). Previous studies have shown that the density contrast between sediments and the basement (here $100 \mathrm{~kg} \cdot \mathrm{m}^{-3}$ ) leads to horizontal gravitational force acting toward the basins (e.g., Le Pichon and Alvarez, 1984; Rey et al., 2001; Rey, 2001). In our experiments, the magnitude of compressional stresses around rift basins is on average $\sim 10 \mathrm{MPa}$ and can reach up to $\sim 30 \mathrm{MPa}$. Stress inversions in basins occur after stress inversions in the lithospheric mantle, and fluctuate in magnitude and depth, with some experiments showing two distinct phases of compressional inversions. At the transition from rift to drift, all experiments show a change in stress patterns, with a number of 
new zones of compressional stress forming in the crust and rift basins (see Suppl. Data Figure SF2 and SF3).

Basement depth inversion - Figure 4 shows the evolution of the average depth of the basin's basement (see Suppl. Data Figure SF4 for all other experiments) for a suite of experiments with divergence velocity of 1,2 and $4 \mathrm{~cm} / \mathrm{yr}$, and a maximum distance between adjacent Moho tracers of 30, 80 and $100 \mathrm{~km}$ at which sedimentation stops. In experiments with no sediment input, the basement subsides monotonically until breakup occurs. When sediments are supplied, the rate and magnitude of the basement subsidence significantly increases due the weight of the sediment infill (Burov and Poliakov, 2001), and breakup is delayed. In all experiments, we observe that for the same percentage of extension, the magnitude of subsidence increases with the extensional velocity (green squares in Figure 4 show the amount of subsidence at $20 \%$ extension). However, because the condition for cessation of sedimentation is meet earlier at faster extensional velocity, the absolute maximum subsidence is smaller for fast extension (Figure 4). As the conjugated margins move apart beyond the threshold distance for sedimentation (shown as circles on Figure 4), all experiments record a significant inversion from basement subsidence to uplift, proportional to the amount of subsidence and sediment loading. This is particularly visible in experiments with moderate divergence velocities $(2 \mathrm{~cm} / \mathrm{yr}$ ) in which the inversion reaches $2 \mathrm{~km}$ (Fig. 4). During this inversion, the maximum, median, and average depths of all basins decrease by about 1 to $2 \mathrm{~km}$, and the sediment pile is stretched and thinned by normal faulting and fault block rotation, some basins being completely attenuated during this process. At that stage, the asthenosphere rises to reach its neutral buoyancy level ( $\sim 3000 \mathrm{~m}$ below sea level), continental breakup is reached (triangles in Figure 4), and the maximum basin depth tends to remain steady or slowly decreases. 


\section{DISCUSSION}

Transient inversions confined to sub-basins have been documented along many continental margins (e.g., Holford et al., 2009; 2014; Cloetingh et al., 2008). These transient inversions are associated to either localized contractional reactivation, or epeirogenic uplift, or to the doming of the asthenosphere during rifting which increases a local gravitational potential energy (GPE) in the rift region forcing stress inversion in sub-basins on the adjacent stretched margins (Suppl. Data Figure SF5, Turcotte and Emerman, 1983; Buck, 1991; Huismans et al., 2001; Rey, 2001; Davis and Kusznir, 2002; Mondy et al., 2018). Of particular importance is the well-documented phase of regional uplift and erosion, called breakup unconformities, which typically precedes the onset of seafloor spreading (Falvey, 1974; Braun and Beaumont, 1989; Franke, 2013; Soares et al., 2012). Our experiments reveal a link between the cessation of sedimentation and a regional uplift 1 to $2 \mathrm{~km}$ in magnitude. We attribute this inversion to the dynamic imbalance resulting from cessation of sedimentation and surface loading of the thinning lithosphere. This imbalance is relaxed through isostatic uplift which drives the observed depth inversion. Our experiments show that basin inversions are particularly strong for moderate extension rates. Indeed, during fast extension only shallow basins with a reduced capacity for depth inversion form. In contrast, during slow extension, diffusive cooling becomes important limiting the potential for isostatic uplift and depth inversion.

\section{CONCLUSIONS}

We show that in a divergent setting, transient periods of stress and depth inversions are the outcome of competing deep to surface processes altering the dynamic balance at both local and regional scales. Upon lithospheric thinning, the asthenosphere is under the isostatic imperative to reach its neutral buoyant level (the elevation of mid-oceanic ridges). The growing dome of 
asthenosphere introduces horizontal gravitational forces acting from the rift region toward the adjacent margins, resulting in an inversion of the stress regime from extensional to compressional in the adjacent lithospheric mantle. The magnitude of these compressional stresses is around $10 \mathrm{MPa}$, and locally can reach up to ca. $30 \mathrm{MPa}$. This result is in agreement with previous work on the 'rift push' force (Davis and Kuznir, 2001; Huismanns et al., 2001; Rey, 2001; Mondy et al. 2018). Our experiments document the important role surface processes play in the dynamics of continental rifting. During extension, the subsidence of the basement is enhanced by the accumulation of sediments. The surface loading due to the growing sedimentary pile mitigates thinning, slows down the exhumation of the asthenosphere, and delays breakup. When the supply of sediments ceases, the dynamic imbalance accelerates the thinning of the lithosphere, including the sedimentary pile, and triggers the isostatic uplift of the lithosphere. This results in a significant depth inversion of the basement (up to $2 \mathrm{~km}$ ), roughly proportional to the thickness of the sedimentary pile. The magnitude and timing of this depth inversion is consistent with the well-documented breakup unconformity, and we propose that cessation of sediment supply could be one of its triggers.

\section{ACKNOWLEDGEMENTS}

PR acknowledges the support from Australian Research Council's ITRH project IH130200012, and ARC LP190100146. The code Underworld is provided by AuScope Ltd., funded under the Australian National Collaborative Research Infrastructure Strategy. We also acknowledge the assistance of resources from the National Computational Infrastructure (NCI), through the National Computational Merit Allocation Scheme supported by the Australian Government; the Pawsey Supercomputing Centre with funding from the Australian Government and the Government of Western Australia. We thank Julian Giordani and Romain Beucher (NCRIS, Auscope) for their expert support with Underworld. 


\section{REFERENCES CITED}

Beucher, R., Moresi, L., Giordani, J., Mansour, J., Sandiford, D., Farrington, R., Mondy, L., Mallard, C., Rey, P., Duclaux, G. and Kaluza, O., 2019, UWGeodynamics: A teaching and research tool for numerical geodynamic modelling: Journal of Open Source Software, 4(36), p.1136.

Boldreel, L.O. and Andersen, M.S., 1993, Late Paleocene to Miocene compression in the Faeroe-Rockall area: Geological Society, London, Petroleum Geology Conference series, v. 4, p. 1025-1034.

Bott, M.H.P., 1992, Modelling the loading stresses associated with active continental rift systems: Tectonophysics, v. 215(1-2), p.99-115.

Buck, W.R., 1991, Modes of continental lithospheric extension. Journal of Geophysical Research: Solid Earth, 96(B12), p.20161-20178.

Burov, E. and Poliakov, A., 2001, Erosion and rheology controls on synrift and postrift evolution: Verifying old and new ideas using a fully coupled numerical model: Journal of Geophysical Research: Solid Earth, v. 106(B8), p.16461-16481.

Braun, J. and Beaumont, C., 1989, A physical explanation of the relation between flank uplifts and the breakup unconformity at rifted continental margins: Geology, v. 17(8), p.760-764.

Crameri, F., Schmeling, H., Golabek, G.J., Duretz, T., Orendt, R., Buiter, S.J.H., May, D.A., Kaus, B.J.P., Gerya, T.V. and Tackley, P.J., 2012, A comparison of numerical surface topography calculations in geodynamic modelling: an evaluation of the 'sticky air' method: Geophysical Journal International, v. 189(1), p. 38-54. 
Davis, M. and Kusznir, N., 2002, Are buoyancy forces important during the formation of rifted margins?: Geophysical Journal International, v. 149, p. 524-533, https://doi.org/10.1046/j.1365-246X.2002.01666.x.

Dewey, J.F., 1989, Kinematics and dynamics of basin inversion: Geological Society, London, Special Publications, v. 44 (1): 352. doi:10.1144/gsl.sp.1989.044.01.20.

Demouchy, S., Tommasi, A., Ballaran, T. B. \& Cordier, P., 2013, Low strength of Earth's uppermost mantle inferred from tri-axial deformation experiments on dry olivine crystals. Physics of Earth and Planetary Interior, v. 220, p. 37-49.

Falvey, D.A., 1974, The development of continental margins in plate tectonic theory: Journal of Australian Petroleum Exploration Association, v. 14, p. 95-107.

Franke, D., 2013, Rifting, lithosphere breakup and volcanism: Comparison of magma-poor and volcanic rifted margins: Marine and Petroleum geology, v. 43, p.63-87.

Hirth, G. and Kohlstedt, D., 2004, Rheology of the upper mantle and the mantle wedge: A view from the experimentalists, in Eiler J., ed., Inside the Subduction Factory, Geophysical Monograph Series, v. 138., Blackwell Publishing, p. 83-105.

Holford, S.P., Turner, J. P., Gree, P. F. and Hillis, R. R., 2009, Signature of cryptic sedimentary basin inversion revealed by shale compaction data in Irish Sea, western British Isles: Tectonics, v. 28, TC4011, doi:10.1029/2008TC002359.

Holford, S.P., Tuitt, A.K., Hillis, R.R., Green, P.F., Stoker, M.S., Duddy, I.R., Sandiford, M., and Tassone, D.R., 2014, Cenozoic deformation in the Otway Basin, southern Australian margin: Implications for the origin and nature of post breakup compression at rifted margins: Basin Research, v. 26, p. 10-37, https://doi.org/10.1111/bre.12035. 
Huismans, R.S., Podladchikov, Y.Y. and Cloetingh, S., 2001, Transition from passive to active rifting: Relative importance of asthenospheric doming and passive extension of the lithosphere: Journal of Geophysical Research: Solid Earth, v. 106(B6), p.11271-11291.

Keen, C.E., 1987: Some important consequences of lithospheric extension. Geological Society, London, Special Publications, v. 28(1), p.67-73.

Le Pichon, X. and Alvarez, F., 1984, From stretching to subduction in back-arc regions: Dynamic considerations: Tectonophysics, 102(1-4), pp.343-357.

Lundin, E. and Doré, A.G., 2002, Mid-Cenozoic post-breakup deformation in the passive margins bordering the Norwegian-Greenland Sea: Marine and Petroleum Geology, v. 19(1), p.79-93.

Lundin, E.R. and Doré, A.G., 2011, Hyperextension, serpentinization, and weakening: A new paradigm for rifted margin compressional deformation: Geology, v. 39(4), p.347-350.

Mondy, L.S., Rey, P.F., Duclaux, G. and Moresi, L., 2018, The role of asthenospheric flow during rift propagation and breakup: Geology, v. 46(2), p.103-106.

Moresi, L., Dufour, F. and Mühlhaus, H.B., 2003, A Lagrangian integration point finite element method for large deformation modeling of viscoelastic geomaterials: Journal of computational physics, v. 184(2), p.476-497.

Moresi, L., Quenette, S., Lemiale, V., Meriaux, C., Appelbe, B. and Mühlhaus, H.B., 2007, Computational approaches to studying non-linear dynamics of the crust and mantle: Physics of the Earth and Planetary Interiors, v. 163(1-4), p.69-82.

Pascal, C. and Cloetingh, S.A., 2009, Gravitational potential stresses and stress field of passive continental margins: Insights from the south-Norway shelf. Earth and Planetary Science Letters, v. 277(3-4), p.464-473. 
Paterson, S. and Luan, F. C., 1990, Quartzite rheology under geological conditions, in Knipe, R. J. and Rutter, E. H., eds, Deformation Mechanisms, Rheology and Tectonics: Geological Society, London, Special Publications 54, p. 299-307.

Péron-Pinvidic, G., Manatschal, G., Minshull, T.A., and Sawyer, D.S., 2007, Tectonosedimentary evolution of the deep Iberia-Newfoundland margins: Evidence for a complex breakup history: Tectonics, v. 26, TC2011, doi:10.1029/2006TC001970.

Rey, P. F., 2001, From lithospheric thickening and divergent collapse to active continental rifting, in Miller, J.A., Holdsworth, R.E., Buick, I.S. and Hand, M., eds, Continental Reactivation and Reworking: Geological Society, London, Special Publications 184, p.7788.

Schlische, R.W., M.O. Withjack, and P.E. Olsen, 2003, Relative timing of CAMP, rifting, continental breakup, and basin inversion: tectonic significance, in Hanes, W.E., McHone, J.G., Renne, P.R., and Ruppel, C., eds., The Central Atlantic Magmatic Province, Insights from Fragments of Pangea: Washington, D.C., American Geophysical Union Geophysical Monograph v. 136, p. 33-60.

Soares, D.M., Alves, T.M., and Terrinha, P., 2012, The breakup sequence and associated lithospheric breakup surface: Their significance in the context of rifted continental margins (West Iberia and Newfoundland margins, North Atlantic): Earth Planetary Science Letters, v. 355-356, p. 311-326.

Turcotte, D.L. and Emerman, S.H., 1983, Mechanisms of active and passive rifting: Developments in Geotectonics, v. 19, p. 39-50.

Wang, Y. F., Zhang, J. F., Jin, Z. M. and Green, H. W., 2012, Mafic granulite rheology: implications for a weak continental lower crust: Earth Planetary Science Letters, 353-354, 99-107. 
Withjack, M.O., Schlische, R.W., and Olsen, P.E., 1998, Diachronous rifting, drifting, and inversion on the passive margin of central eastern North America: An analog for other passive margins: American Association of Petroleum Geologists, Bulletin, v. 82, p. 817835.

Zhong, S. and Watts, A. B., 2013, Lithospheric deformation induced by loading of the Hawaiian Islands and its implications for mantle rheology: Journal of Geophysical Research, 118, 1-24.

Zoback, M.L., 1992, First- and second-order patterns of stress in the lithosphere: The World Stress Map Project: Journal of Geophysical Research: Solid Earth, 97(B8), pp.1170311728.

\section{FIGURES CAPTION}

Figure 1. We map a model of continental lithosphere over a computational grid with a cell resolution of $1 \mathrm{~km}$. The model is laterally uniform but includes i/ a $200 \mathrm{~km}$ wide zone where the crust is pre-weakened with gaussian damage (blue shading), and ii/ a $2 \times 10 \mathrm{~km}$ volume of crust (notch) placed underneath the Moho. Both heterogeneities localise deformation in the centre of the domain, mitigating boundary effects. Kinematic boundary conditions are applied to the vertical walls. The graphs show the differential stress (for a nominal strain rate of 1e-15 $\mathrm{s}^{-1}$ ) and geotherm at the start of all experiments. The upper crust is made of wet quartzite (Paterson and Luan, 1990), the lower crust consists of mafic granulite (Wang et al., 2012), and the mantle is made of wet olivine (Hirth and Kohlstedt, 2003). Above the crust, a "sticky-air" layer with viscosity of 1e18 Pa.s simulates a free surface (Crameri et al., 2016).

Figure 2. Evolution of extension models with divergent velocity of $2 \mathrm{~cm} / \mathrm{yr}-\mathrm{A}$ ) without 
sedimentation, and B) with sedimentation up to $1 \mathrm{~km}$ depth below sea level, and until two adjacent tracers at the Moho reach a distance of $80 \mathrm{~km}$. Material colours are the same as Figure 1. Sediments are dark red. Semi-transparent blue-green colours show strain-rate. White contours show the $1 \%$ and $2 \%$ melt fraction. Coloured contours show isotherms $100^{\circ} \mathrm{C}$ apart.

Figure 3. Evolution of the stress field for models with divergent velocity of $2 \mathrm{~cm} / \mathrm{yr}$. A/ Stress field for an experiment without sediment supply, and B/ with sediment supply. The shallow thick black contour follows the basement surface, the white contour delineates the outline of the lower crust, and the grey contour in the mantle is the $1350^{\circ} \mathrm{C}$ isotherm. Colour intensity shows the deviatoric stress magnitude, and greyscale colours are regions with non-definable Andersonian stress (none of the principal stress axes is close to vertical). Red arrows in panels B2 and B4 point to inverted sub-basins.

Figure 4. Average basement depth as a function of total extension, for various extensional velocity and sediments supply. Sedimentation ceases when the threshold distance between two adjacent tracers at the Moho is reached (here 30,80 or $100 \mathrm{~km}$ ). Circles mark when sedimentation stops, triangles mark when continental breakup occurs. See Supplementary Figure SF4 for same analysis on maximum and median basement depth. Green squares show the amount of subsidence at $20 \%$ extension. 


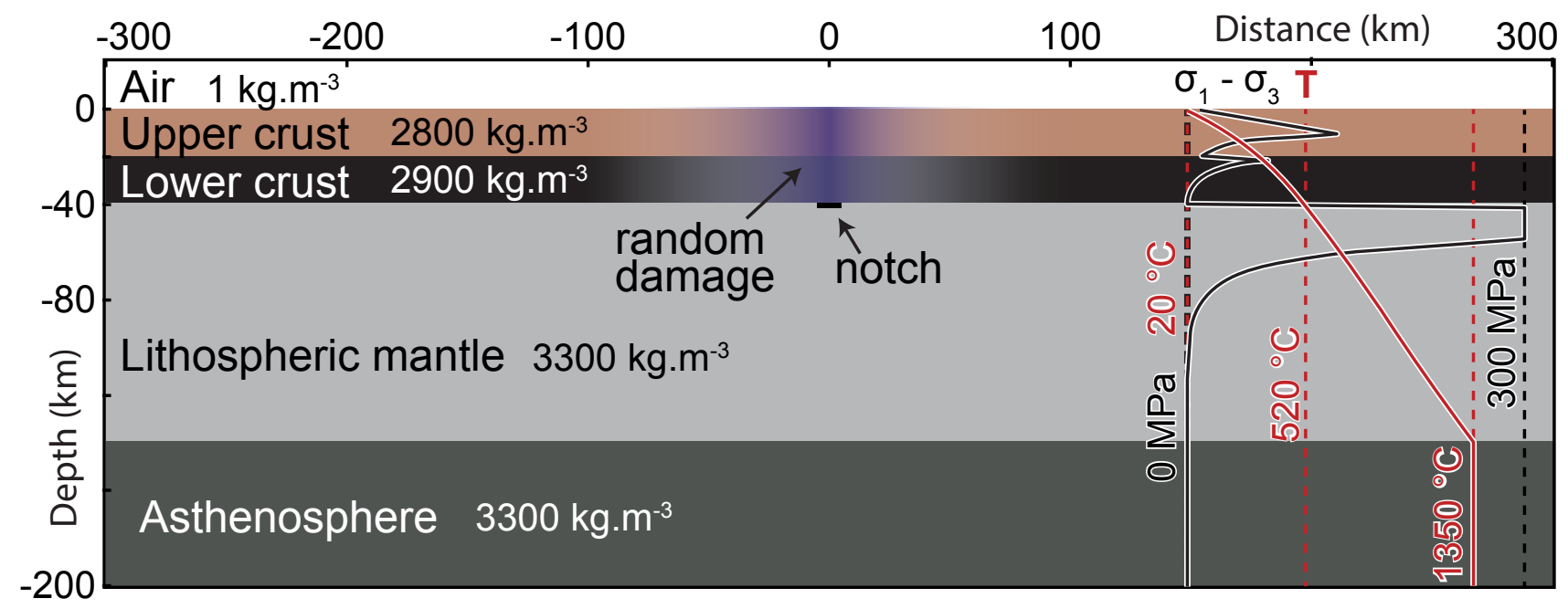



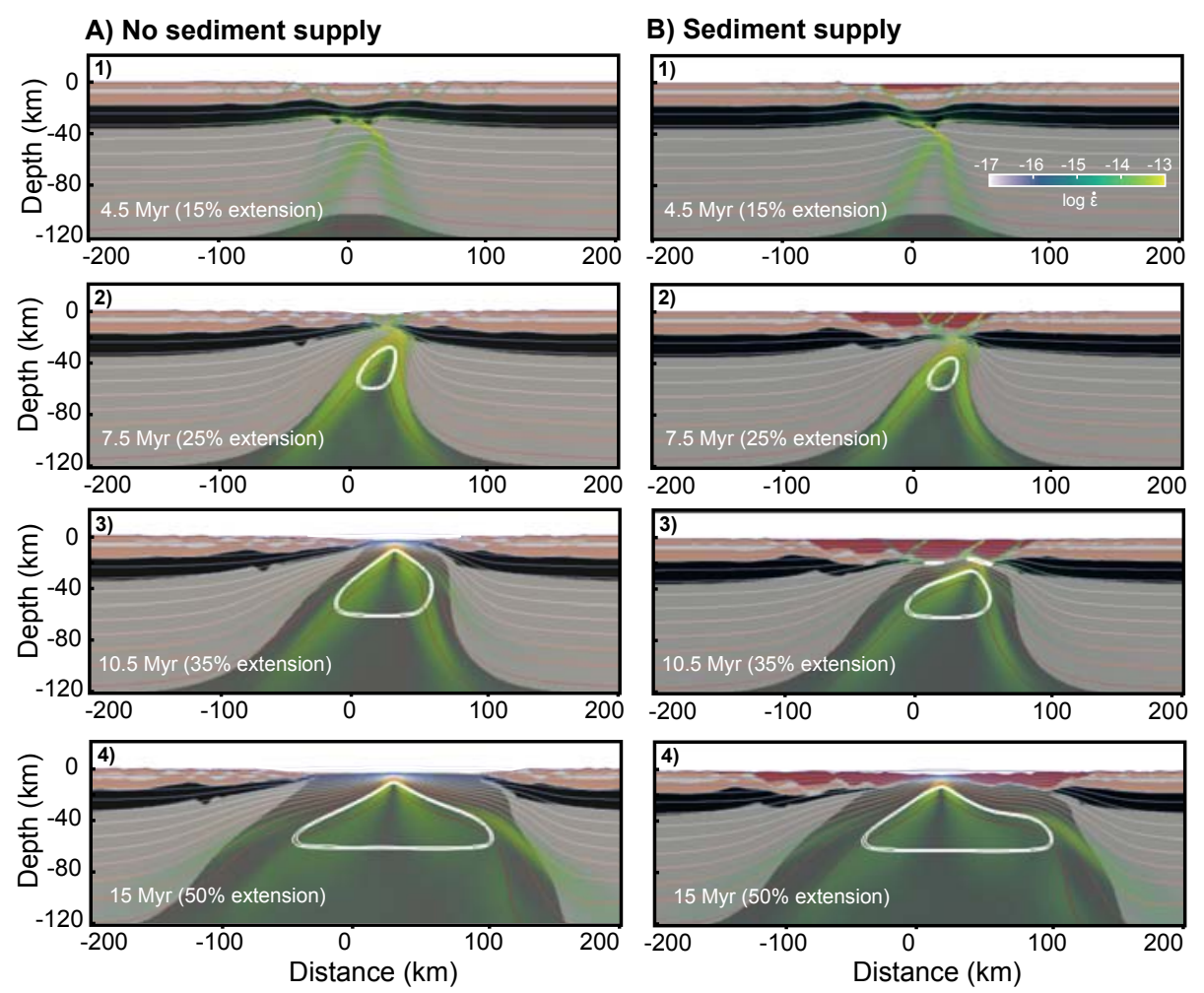


\section{Figure 3}

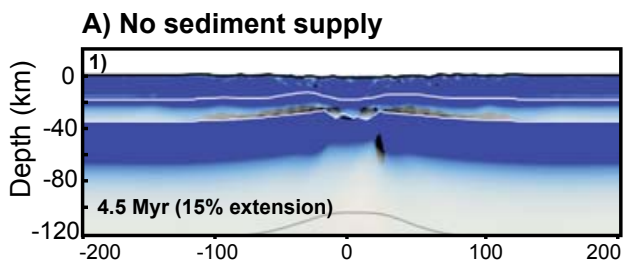

\section{B) Sediment supply}
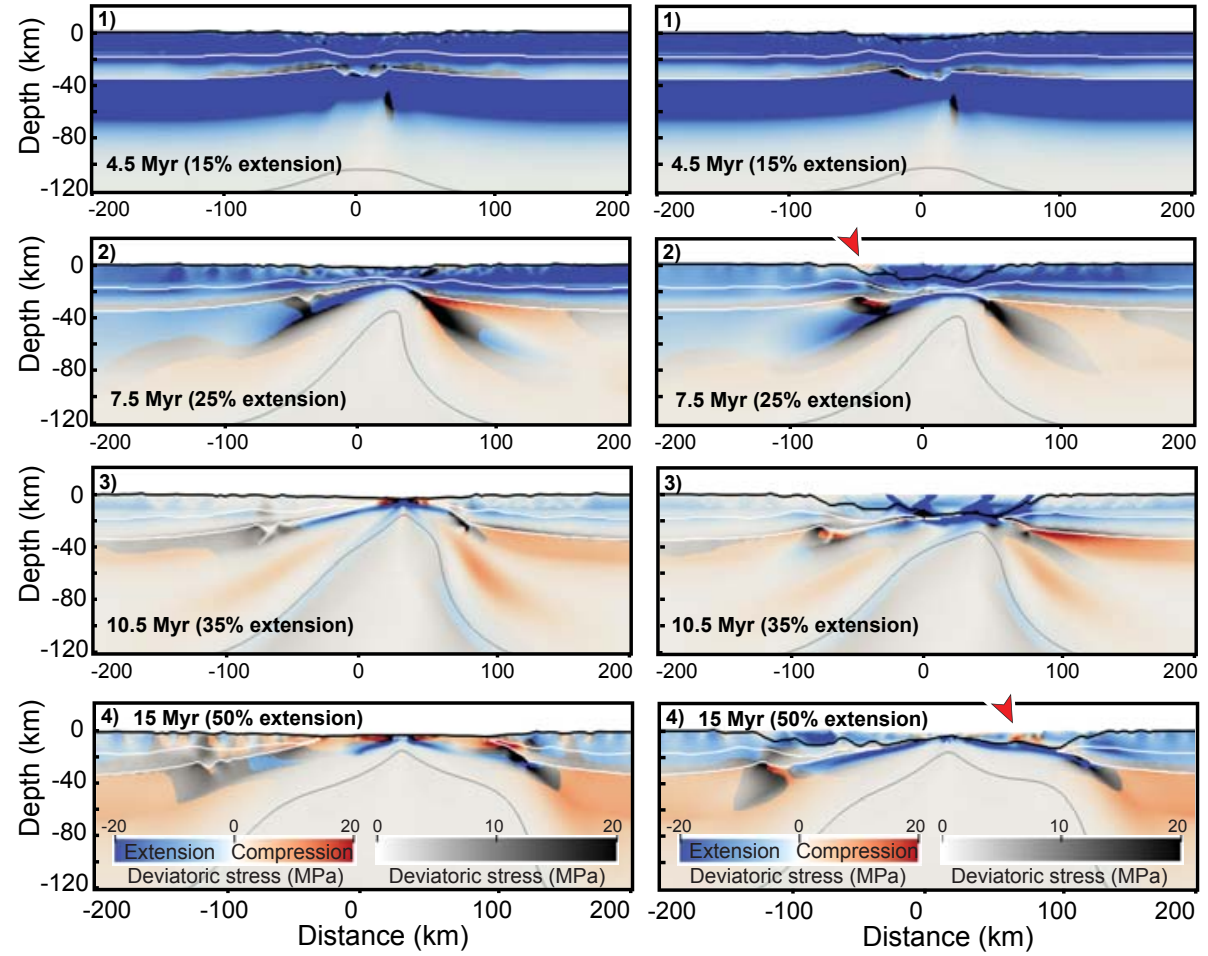


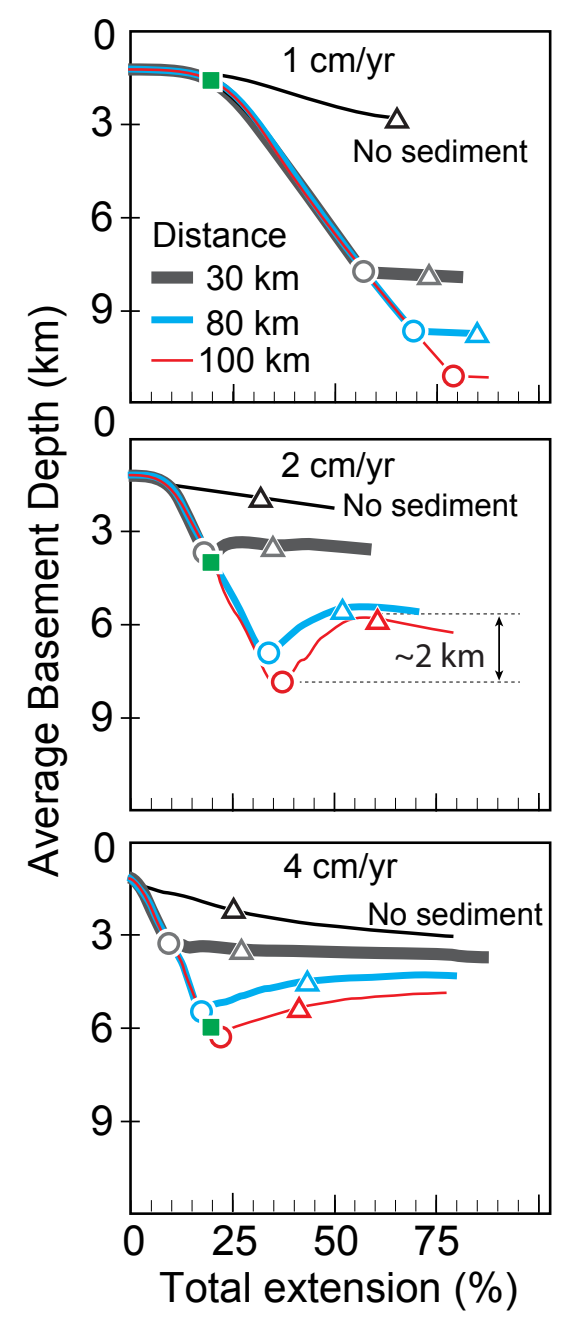

